INTERNATIONAL JOURNAL OF SYSTEMATIC BACTERIOLOGY

Vol. 16, No. 4 October 1966 pp. 427-433

\title{
A SUMMARY OF THE BIOCHEMICAL REACTIONS OF ARIZONA ARIZONAE
}

\author{
W. H. Ewing and M. A. Fife
}

Department of Health, Education, and Welfare, Public Health Service, Communicable Disease Center Atlanta, Georgia

\begin{abstract}
The results of investigations of the biochemical reactions given by members of the genus Arizona Kauffmann and Edwards are summarized and compared to those reported by several other investigators, and to the reactions obtained with the neotype strain of Arizona arizonae Kauffmann and Edwards. Tests of value in the differentiation of Salmonella, Arizona, and Citrobacter are listed. A definition of the genus Arizona
\end{abstract}

The earliest known description of a microorganism now included in the genus Arizona was given by Caldwell and Ryerson (1939). These investigators isolated several similar cultures from reptiles, which they designated Salmonella sp. (Dar-es-Salaam type, variety from Arizona) because the bacteria liquefied gelatin. One of the cultures so characterized by Caldwell and Ryerson was studied by Kauffmann (1941) who proposed the name Salmonella arizona for it. Later, studies by Peluffo, Edwards and Bruner (1942), Edwards, Cherry and Bruner (1943), Edwards and West (1945), and Edwards, West and Bruner (1947) indicated that the strains described by Caldwell and Ryerson (1939) actually were representatives of a large group of biochemically and serologically related bacteria. The name 'Arizona group' was applied to these particular bacteria by Edwards, West and Bruner (1947) who characterized 190 antigen groups and 55 serologic types among the cultures at hand and who reported that the microorganisms fermented lactose with varying avidity and liquefied gelatin but did not utilize dulcitol nor D-tartrate. Also, Edwards, Cherry and Bruner (1943) noted that most of the strains reported upon utilized malonate. Schaub (1948) mentioned that members of the Arizona group utilized malonate whereas salmonellae did not. 
Table 1. Comparison of summaries of biochemical reactions given by cultures of $\mathrm{A}$. arizonae reported by the authors (150), other investigators (76), and those of the neotype culture.

\begin{tabular}{|c|c|c|c|c|c|}
\hline Test or substrate & & $\frac{\text { cultures }}{z_{+}} \frac{\left.z_{t}\right)^{*}}{}$ & & 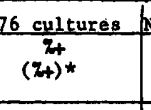 & $\begin{array}{l}\text { Neotype culture } \\
\text { ATCC } 13314 \\
\text { NCTC } 8297 \\
\text { CDC } 3392-57 \\
\end{array}$ \\
\hline Hydrogen sulfide & + & 98.7 & + & 100 & + \\
\hline Urease & - & 0 & - & & - \\
\hline Indol & - & 2 & - & 0 & - \\
\hline Methyl red (37 C) & + & 100 & + & 100 & + \\
\hline Voges-Proskauer (37 C) & - & 0 & - & 0 & - \\
\hline Citrate (Simmons') & + & $98.7(1.3)$ & + & 100 & + \\
\hline RCN & - & 8.7 & - & & - \\
\hline Mot1lity & + & 100 & + & 100 & + \\
\hline Gelatin (22 C) & $(+)$ & (92) & $(t)$ & 100 & (t) $12 \mathrm{da}$ \\
\hline Lysine decarboxylase & + & 100 & & & $+1 \mathrm{da}$ \\
\hline Arginine dihydrolase & $(+)$ or & $12.7(84.6)$ & & & $+2 d a$ \\
\hline Ornithine decarboxylage & + & 100 & & & $+1 \mathrm{da}$ \\
\hline Phenylalanine deaminase & - & 0 & & & - \\
\hline $\begin{array}{c}\text { Glucose acid, } \\
\text { gas }\end{array}$ & $\begin{array}{l}+ \\
+\end{array}$ & $\begin{array}{l}100 \\
99.3\end{array}$ & + & $\begin{array}{l}100 \\
100\end{array}$ & + \\
\hline Lactose & d & $61.3(16.7)$ & d & $13.1(65.8)$ & (+) $10 \mathrm{da}$ \\
\hline Sucrose & - & 4.7 & - & 0 & - \\
\hline Mannitol & + & 100 & + & 100 & + \\
\hline Dulcitol & - & 0 & - & 0 & - \\
\hline Salicin & - & $4.7(3.3)$ & - & 1.3 & - \\
\hline Adonitol & - & 0 & - & 0 & - \\
\hline Inositol & - & 0 & - & 0 & - \\
\hline Sorbitol & + & 97 (2) & + & 100 & + \\
\hline Arabinose & + & 98 (1) & + & 100 & + \\
\hline Raffinose & - & $5(1)$ & - & & - \\
\hline Rhamnose & + & $93(5)$ & + & 100 & + \\
\hline
\end{tabular}

* Figures in parentheses indlcate percentages of delayed reactions ( 3 or more days) ,$+ 90 \%$ or more positive within one or two days' incubation

$(+)$, positive reaction after 3 or more days

,- 907 or more gave no reaction

+ or - , majority of strains positive, occasional cultures negative

- or $t$, majority of cultures negative, occasional strains positive

$(t)$ or $t$, majority of reactions delayed, some occur within 1 or 2 days

d, different reactions: $+,(+),-$ 
Table 1. (cont.)

\begin{tabular}{|c|c|c|c|c|c|}
\hline Test or substrate & 150 & 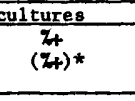 & & $\frac{\text { cultures }}{z_{+}}$ & \begin{tabular}{|l|} 
Neotype culture \\
ATCC 13314 \\
NCTC 8297 \\
CDC $3392-57$ \\
\end{tabular} \\
\hline Malonate & + & $92.6(0.7)$ & + & & + \\
\hline Mucate & d & $56.6(2.7)$ & + & 98.1 & $-\quad+$ \\
\hline Jordan's tartrate & - & 5.3 & - or + & 20.8 & - \\
\hline Sterns' glycerol & + or - & 86.5 & + & & + \\
\hline Sodium acetate & + or $(t)$ & $76.9(17.3)$ & & & \\
\hline Sodium alginate & - & 0 & & & \\
\hline Lipase: corn oil & - & 0 & & & \\
\hline Mal tose & + & 96 & + & 100 & + \\
\hline xylose & + & 100 & + & 100 & + \\
\hline Trehalose & + & 100 & + & 100 & + \\
\hline Cellobiose & d & $1(72)$ & & & \\
\hline Glycerol & $+\operatorname{or}\left(t^{W}\right)$ & $(37.8)$ & & & (t) $6 \mathrm{da}$ \\
\hline Alpha methyl glucoside & - & 0.9 & & & - \\
\hline Erythritol & - & 0 & & & - \\
\hline Esculin & - & 0.9 & & & - \\
\hline Beta galactosidase & + & 100 & & & + \\
\hline Nitrate to nitrite & + & 100 & & & + \\
\hline Oxidation - fermentation & $F$ & 100 & & & $+(F)$ \\
\hline Oxidase & - & 0 & & & \\
\hline \multicolumn{6}{|l|}{ Organic acids ** } \\
\hline cltrate & $(+)$ & $4.7(93.3)$ & + & & - \\
\hline D-tartrate & $(+)$ or & $(83.3)$ & - & 1.8 & - \\
\hline
\end{tabular}

* Figures in parentheses indicate percentages of delayed reactions ( 3 or more days) * Method of Kauffiman and Petersen, 1956

F, Glucose utilized fermentatively

w, Weakly positive reactions 
Kauffmann and Edwards (1952) employed the generic term Arizona and the species name Arizona arizonae and listed characters by means of which these bacteria could be differentiated from Salmonella and other Enterobacteriaceae. Ewing (1963) used Arizona arizonae as the species name for the serotypes of the genus Arizona (Genus II of the Tribe Salmonelleae).

The results of biochemical tests obtained by several investigators in their studies with strains now known as $A$. arizonae are summarized in Table 1. A total of 76 cultures were examined by the following investigators: Caldwell and Ryerson(1939) 3 strains; Peluffo, Edwards and Bruner (1942) 7; Edwards, Cherry and Bruner (1943) 44; Hinshaw and McNeil (1944) 7; Edwards and West (1945) 1; Hinshaw and McNeil (1946) 9; Edwards, van oye, and McWhorter (1955) 3; and Edwards, LeMinor and McWhorter (1956) 2 strains. Some of these investigators reported the results of tests on certain substrates, but the percentage of positive reactions could not be determined, or the numbers of cultures tested were too small to be meaningful. In these instances percentages were not listed on Table 1. For example, Edwards, Cherry and Bruner (1943) reported that most of their strains utilized malonate and that most of the cultures catabolized citrate in the medium of Kauffmann and Buron (1939, loc. cit.) which was similar to that used by Kauffmann and Petersen (1956). Ellis, Edwards and Fife (1957) studied 1136 cultures of Salmonella and 619 strains of the genus Arizona and confirmed and extended the report of the above-mentioned investigators regarding utilization of mucate, malonate, Dtartrate, and citrate.

Ewing, Fife, and Davis (in press, 1965) reviewed the pertinent literature on the biochemical reactions given by cultures of $A$. arizonae, reported the results of complete examinations of 150 cultures, and listed means by which the three genera of the tribe Salmonelleae may be differentiated. The results of their studies on 150 cultures also are summarized in Table 1 . The results obtained with the neotype strain of $A$. arizonae are included in Table 1 for comparison.

Biochemical tests of particular value in the differentiation of members of the genera Salmonella, Arizona, and Citrobacter are given in Table 2. As regards Table 2, it should be noted that the reactions given by cultures of Citrobacter on urea medium are in no way comparable to the rapid, strong reactions given by strains of the genus Proteus. On the contrary, urease activity in cultures of Citro- 


\begin{tabular}{|c|c|c|c|c|c|c|}
\hline \multirow[b]{2}{*}{ Test or substrate } & \multicolumn{2}{|c|}{ Salmone11a } & \multicolumn{2}{|c|}{ Arizona } & \multicolumn{2}{|c|}{ Citrobacter $^{2}$} \\
\hline & & $(2+) *$ & & $\begin{array}{c}z_{+} \\
\left(z_{+}\right) *\end{array}$ & & $\frac{z+}{(z+) *}$ \\
\hline Urease & - & 0 & - & 0 & $d$ & $69.4(6.9)$ \\
\hline $\mathrm{rCN}$ & - & $0.3(0.3)$ & - & 8.7 & + & $96.2(0.9)$ \\
\hline Celatin (22 C) & - & $(1.3)$ & $(+)$ & (92) & - & $(0.9)$ \\
\hline Lysine decarboxylase & + & 97.7 & + & 100 & - & 0 \\
\hline Ornithine decarboxylase & + & 100 & + & 100 & d & $17.2(0.2)$ \\
\hline Lactose & - & 1 & d & $61.3(16.7)$ & $(t)$ ort & $39.3(50.9)$ \\
\hline Sucrose & - & 0.7 & - & 4.7 & d & $15.3(9.4)$ \\
\hline Dulcitol & + & 98.3 & - & 0 & d & $59.4(0.7)$ \\
\hline Inositol & d & $42.8(1)$ & - & 0 & - & $3.3(1.9)$ \\
\hline Cellobiose & $(+)$ ort & $5.4(88.1$ & d & $1(72)$ & $\operatorname{tar}(t)$ & $60.8(38)$ \\
\hline Malonate & - & 0.7 & + & $92.6(0.7)$ & d & $21.8(0.7)$ \\
\hline Jordan's tartrate & + & $92.5(1.1)$ & - & $5.3(19.3)$ & + & 100 \\
\hline Beta galactosidase & - & 1.5 & + & 100 & for- & 74.4 \\
\hline Organic ac1ds ** & & & & & & \\
\hline $\begin{array}{l}\text { citrate } \\
\text { D-tartrate }\end{array}$ & + & $\begin{array}{ll}96 & (4) \\
91 & (5.3)\end{array}$ & $\begin{array}{l}(t) \\
(t) \text { or }-\end{array}$ & $\begin{array}{r}4.7(93.3 \\
(83.3)\end{array}$ & $\begin{array}{l}(+) \text { ort } \\
(t)\end{array}$ & $\begin{array}{r}49.2(49.5) \\
(90.9)\end{array}$ \\
\hline
\end{tabular}

1

2 Sumary of reactiong obtalned with 582 strains (Davis and Bwing, in press)

Summary of reactions given by 315 cultures (Bwing and Ball, In presB)

* Figures in parentheses Indicate percentages of delayed reactions ( 3 or more days)

** Method of Kauffmann and Petersen (1956). For details regarding these reactions especially the time elements involved, the reader is referred to $\mathrm{B} 1118$, Edwards, and Fife (1957) and to Ewing, Fife, and Davia (in press).

+, $90 \%$ or more positive within one or two days' incubation

(4), positive reaction after 3 or more days

-, $90 \%$ or more gave no reaction

* or -, majority of strains positive, occasional cultures negative

- or $t$, majority of cultures negative, occasional strains positive

$(t)$ or $t$, majority of reactions delayed, some occur within 1 or 2 days

d, different reactions:,$+(+)$, - 

Table 2. Differentiation of Salmonella, Arizona, and Citrobacter (reactions of typical cultures). 
bacter is weak and requires 18 to 20 or more hours of incubation before evidence of urease activity appears. Nonetheless, when positive, even weakly so, the test for urease is of considerable differential value. The $5(0.9 \%)$ cultures of Citrobacter that liquefied gelatin in nutrient medium did so only after prolonged incubation ( 30 days or more) and the reactions were weak. The $19.3 \%$ of cultures of Arizona listed as delayed positives (Table 2) on Jordan's tartrate medium yielded doubtful or very weak reactions after 5 to 7 days, hence the negative sign was used (see footnote, Table 2 , regarding $90 \%$ levels). All of the strains of Arizona tested in this study gave evidence of $\beta$-galactosidase activity. However, it is known that occasional cultures may give negative results in this test (i.e., the ONPG test). For example, Lubin and Ewing (1964) reported that $7.2 \%$ of 446 cultures of $\underline{A}$. arizonae tested gave no evidence of $\beta$-galactosidase activity.

From the data given in Tables 1 and 2 it is apparent that the genus Arizona (and the species A. arizonae) is a definite entity, which may be characterized and which may be differentiated from the genus Salmonella and the genus Citrobacter. Therefore, the following definition of the genus Arizona Kauffmann and Edwards (1952) is proposed:准

The genus Arizona is composed of motile bacteria that conform to the definitions of the family Enterobacteriaceae and the tribe Salmonelleae. Urease is not produced and growth does not occur in medium containing potassium cyanide. Lysine, arginine, and ornithine are decarboxylated, sodium malonate is utilized, gelatin is liquefied slowly in nutrient medium, and lactose is fermented by the majority of cultures. With few exceptions acid is not produced in Jordan's tartrate medium. Dulcitol and inositol are not fermented and salicin is utilized infrequently.

The type species is Arizona arizonae Kaufmann and Edwards.

* Definitions of the family Enterobacteriaceae, the tribe Salmonellae, and the genera Salmonella and Citrobacter are given elsewhere (Ewing, in press). 


\section{References}

Caldwell, M. E. and D. L. Ryerson. 1939. Jour. Infectious Dis. , 65:242-245.

Davis, B. R. and W.H. Ewing. CDC Publication. In press. Edwards, P.R., W. B. Cherry and D. W. Bruner. 1943. Jour. Infectious Dis., 73:229-238.

and M. G. West. 19 $\overline{45}$. Ibid. , 77:185-186. and D.W. Bruner. 1947. Arizona group of paracolon bacteria. Bull. 499. Kentucky Agr. Exper. Sta. , University of Kentucky, Lexington.

, E. van Oye and A. C. McWhorter. 1955. Ann. Soc. Belge Trop. Med., 35:145-150. , L. LeMinor, and A. C. McWhorter. 1956. Ann. Inst. Pasteur, 90:791-792.

Ellis, R. J., P. R. Edwards, and M. A. Fife. 1957. Pub. Hlth. Lab. , 15:89-93.

Ewing, W. H. 1 $\overline{963}$. Intern. Bull. Bact. Nomen. Tax. , 13: 95- 110 . and M. M. Ball. CDC Publication. In press. - M.A. Fife, and B. R. Davis. 1965. Biochemical reactions given by cultures of Arizona arizonae. CDC Publication, Communicable Disease Center, Atlanta. In press.

Hinshaw, W. R. and E. McNeil. 1944. Cornell Vet. 34:248254. and - 1946. Jour. Bact. 51:281-286.

Kauffmann, F. 1941. Acta Path. Microbiol. Scand. 18:351366. and P.R. Edwards. 1952. Intern. Bull. Bact. Nomen. Tax., $2: 2-8$.

and A. Petersen. 1956. Acta Path. Microbiol. Scand. 38: $481-491$.

Lubin, A. H. and W.H. Ewing. 1964. Pub. Hlth. Lab. 22: 83-101.

Peluffo, C. A., P. R. Edwards, and D.W. Bruner. 1942. Jour. Infectious Dis., 70:185-192.

Schaub, I. G. 1948. Bull. Johns Hopkins Hosp. , 83:367-382. 
